\title{
鳥取砂丘海岸における大規模養浜の効果 と安定性の検討
}

\author{
涉谷＼cjkstart容子 1 ・田村 直貴 2 ・太田 啓吾 3 ・ \\ 黒岩 正光 4 ・松原 雄平5 \\ 1 正会員 鳥取大学 特命准教授（干680-8551 鳥取県鳥取市湖山町南 4-101） \\ E-mail: shibutani.yoko@sankaku.tottori-u.ac.jp \\ 2 (株) 日本港湾コンサルタント（テ651-0086 神戸市中央区磯上通 4-1-6 シオノギ神戸ビル） \\ 3 神戸市建設局中部建設事務所（†652-0041 神戸市兵庫区湊川町 2 丁目 1 番 12 号） \\ 4 正会員 鳥取大学大学院工学研究科教授（广 $680-8552$ 鳥取県鳥取市湖山町南 4-101) \\ E-mail: kuroiwa@cv.tottori-u.ac.jp \\ 5 正会員 鳥取大学大学院工学研究科教授（干680-8552 鳥取県鳥取市湖山町南 4-101) \\ E-mail: matubara@cv.tottori-u.ac.jp
}

\begin{abstract}
全国的に砂浜海岸の侵食問題は深刻化しており，鳥取県東部に位置する鳥取砂丘海岸でも海岸侵食が激 化し，危機的状況であった。一方で港湾や河口では堆砂問題が生じていたことから，平成 17 年度から浚渫 土砂を侵食域に投入するサンドリサイクルを実施している．本研究ではこのサンドリサイクルによる土砂 投入の効果を検証するとともに，平成 22 年度および 23 年度に行われた大規模養浜の効果とその安定性の 検討を行った．土砂量変化および汀線変化の解析を行い，大規模養浜により海岸全体の土砂量は一時的に 増加し，その後はもとの土砂量にもどりつつあるが，汀線の回復は現在もある程度維持されていることが 確認された．特に，サンドリサイクル後も侵食傾向であった土砂投入付近の汀線は大規模養浜により前進 し，その後も汀線は維持されていることがわかった。
\end{abstract}

Key Words : sediment transport,beach nourishment, shoreline change,seasonal change

\section{1. はじめに}

湯山福部海岸，通称鳥取砂丘海岸は，鳥取県東部に位 置し，一級河川である千代川を土砂供給源とする東西約 $7 \mathrm{~km}$ の砂浜海岸である．昭和40年代より千代川河口の付 け替えや鳥取港の拡張工事，防波堤の建設などの社会基 盤整備が行われ，鳥取砂丘海岸では著しい地形変化が生 じた．特に，海岸の中央部にある鳥取砂丘前面で海岸侵 食が深刻化していた。 その一方で，鳥取港や周辺の漁港 などでは航路埋没が問題となっていた。これらの問題を 解決するために, 鳥取県では平成17年度より総合的な土 砂管理の一環として, 鳥取港および塩見川などに堆積し た土砂を有効活用し，鳥取砂丘海岸の侵食域一養浜寸る サンドリサイクル (年間約 3 万 $\left.\mathrm{m}^{3}\right)$ を行っている.さら に, 平成22年度および平成23年度には通常の浚渫土砂の 投入の他に，多量の工事掘削土砂 (約 10 万 $\mathrm{m}^{3}$ ) が陸上貯 留（大規模養浜）されている. 涉谷ら ${ }^{1)}$ は漂砂系全体の 土砂移動特性の把握を行うとともに，サンドリサイクル の効果検証を行った．そこでは，鳥取砂丘海岸は季節波 浪による地形変動を繰り返しながら, サンドリサイクル
開始以降，土砂量は増加し，一部区間を除いて汀線も概 衩安定もしくは前進傾向であることから, 浚渫土砂のリ サイクルは一定の効果があることが示された．また，大 規模養浜による多量の土砂の歩留まりやその効果の持続 について注視する必要が述べられていた，そこで，本研 究では, 大規模養浜後の土砂移動と土砂投入付近の詳細 な汀線変化に着目し，その後の土砂動態の把握および大 規模養浜の安定性の検討を行う。

\section{2. 鳥取砂丘海岸について}

\section{(1) サンドリサイクルの概要}

図-1に鳥取砂丘海岸の概要およびサンドリサイクル による土砂投入位置と人工リーフの整備状況（図右上） をあわせて示す，図中央部の赤丸は陸上養浜位置を黄丸 は沖合養浜位置を表している. 平成26年度までの土砂投 入量を図-2に示す．図の凡例は浚渫場所を表したもので, 国道 9 号駆馳山BP工事掘削土砂が大規模養浜土砂にあ たる. また，土砂投入先ごとの養浜量を表-1に示す. 


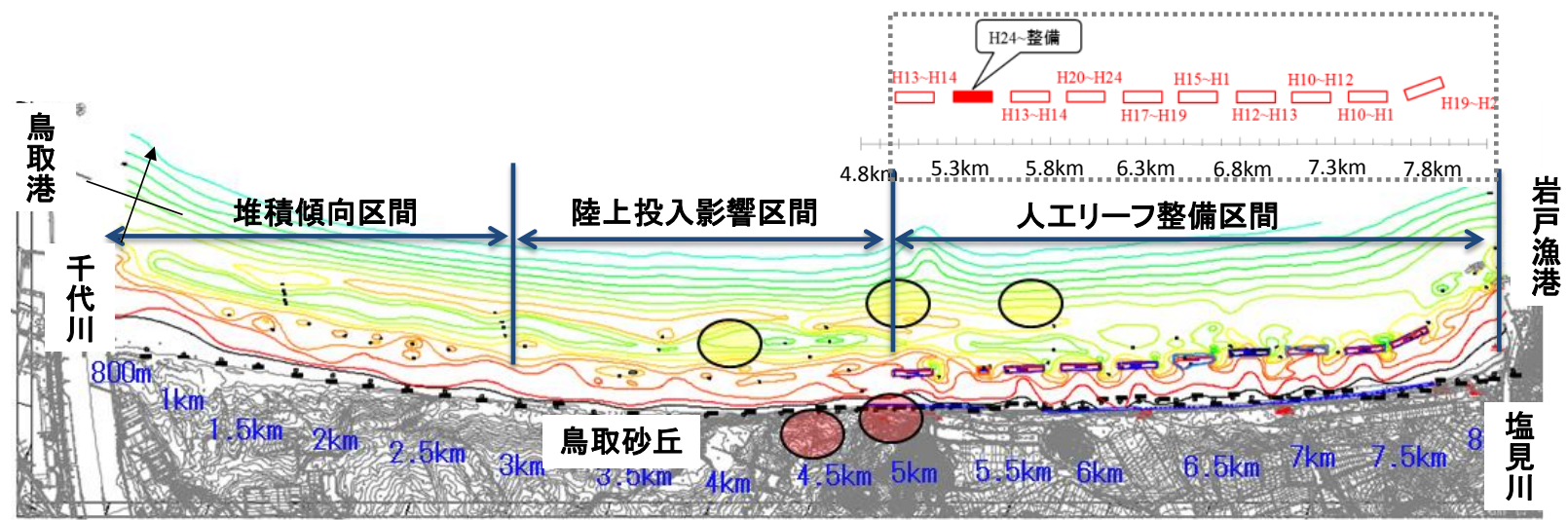

図-1＼cjkstart鳥取砂丘海岸の概要および養浜位置（平成 26 年度鳥取県東部沿岸土砂管理連絡調整会議資料を基に作成）

平均的なサンドリサイクルは，鳥取港および塩見川河口 などの浚渫土砂を約 3 万 $\mathrm{m}^{3}$ 沖合養浜し, 数千 $\mathrm{m}^{3}$ 程度陸上 養浜している，鳥取港においては航路維持のため毎年2 $\sim 3$ 万 $\mathrm{m}^{3}$ の土砂浚渫を行っており, 浚渫量と投入量の経 年変化からも, 侵食域へ投入した土砂の一部は鳥取港一 戻ってきていることが明らかとなっている(澁谷ら ${ }^{1)}$ ).

\section{(2) 波浪特性と地形変化}

図-3にNOWPHAS鳥取(北緯 $35^{\circ} 33^{\prime} 00^{\prime}$, 東経 $134^{\circ}$ $10 ’ 00 ” ：$ 鳥取港沖)の平成16年から平成26年までの観 測波浪（日平均有義波高および有義波周期）を示す。日 本海側の季節風の影響により, 有義波高だけでなく, 有 義波周期も季節変化を繰り返していることがよくわかる.

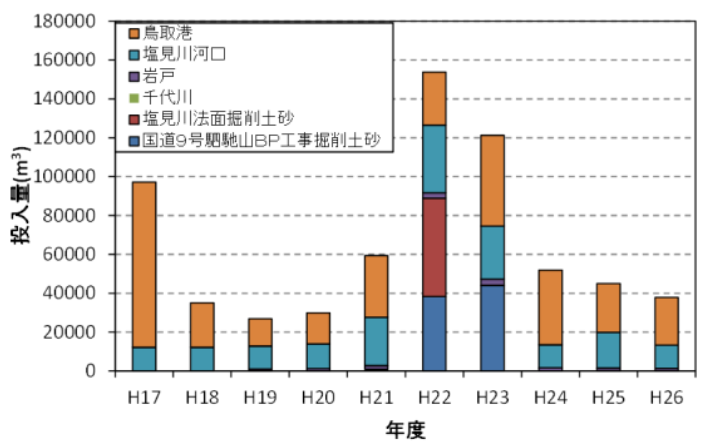

図-2 土砂投入量 (平成 26 年度鳥取県東部沿岸土砂管理連絡調 整会議資料より)

表-1 土砂投入量と投入箇所

\begin{tabular}{|c|r|r|r|}
\hline & \multicolumn{3}{|c|}{ 土砂投入量 $\left(\mathrm{m}^{3}\right)$} \\
\hline 期間 & \multicolumn{1}{|c|}{ 沖 } & \multicolumn{1}{|c|}{ 陸上 } & \multicolumn{1}{c|}{ 計 } \\
\hline 平成17年 & 94010 & 3187 & 97197 \\
\hline 平成18年 & 31867 & 3236 & 35103 \\
\hline 平成19年 & 23205 & 3570 & 26775 \\
\hline 平成20年 & 26372 & 3587 & 29959 \\
\hline 平成21年 & 55268 & 4124 & 59392 \\
\hline 平成22年 & 61482 & 92334 & 153816 \\
\hline 平成23年 & 77151 & 44100 & 121251 \\
\hline 平成24年 & 48040 & 3900 & 51940 \\
\hline 平成25年 & 26262 & 9500 & 35762 \\
\hline 平成26年 & 34995 & 2880 & 37875 \\
\hline 合計 & 478652 & 170418 & 649070 \\
\hline
\end{tabular}

図-4に夏季（4月から9月）と冬季（10月から3月）の観 測波浪の波向別出現頻度をそれぞれ示す．夏季の期間は 有義波高 $2 \mathrm{~m}$ 以下の波浪がほとんどで, 北北東からの波浪 が卓越する.一方, 冬季は北から北北西の波浪が卓越し, 有義波高 $3 \mathrm{~m}$ を超える比較的大きい波浪が頻来する.この ため海底地形も季節的な変化を繰り返しているが，冬季 の波浪エネルギーにより海底地形は大きく変動している と考えられ，千代川からの供給土砂の平均的な移動は西 側から東側である.しかし，鳥取港沖の防波堤建設など により遮蔽域が形成され，鳥取砂丘前面より西側の漂砂 の流れは東から西向きとなっているのが現状である.

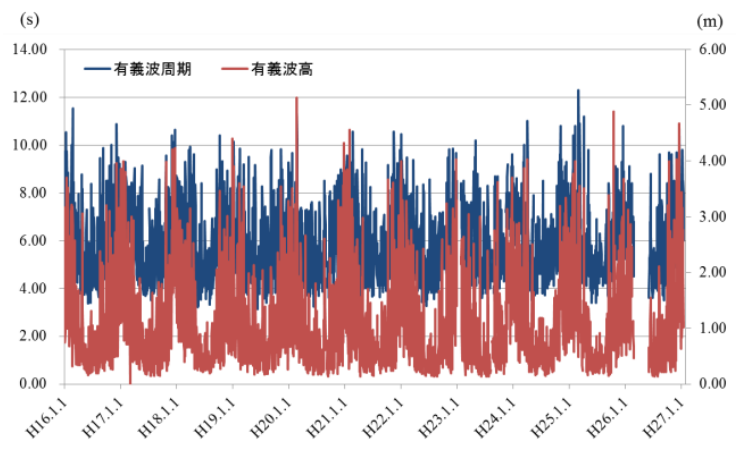

図-3 NOWPHAS 鳥取の有義波高および有義波周期

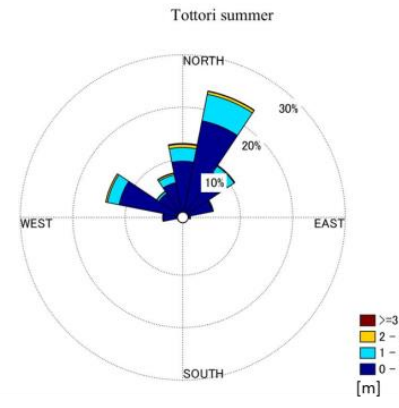

(a) 夏季

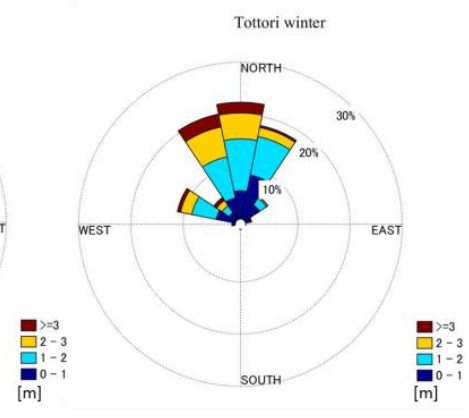

(b) 冬季
図-4 季節別の有義波高および有義波波向 


\section{3. 鳥取砂丘海岸の土砂量変化}

鳥取県が実施している年 2 回の深浅測量結果（鳥取県 土整備事務所提供）を用い，平成14年から平成26年まで の土砂量を算出し, サンドリサイクル前後および大規模 養浜後の土砂量の変化について考察を行う.土砂量の算 出は, 深浅測量の測量誤差を考え $\pm 0.25 \mathrm{~m}$ 以下は除外し, 涉谷ら ${ }^{1)}$ と同様に, 千代川河口右岸側を $0 \mathrm{~m}$ とて, 沿岸 方向 $500 \mathrm{~m}$ 加 $7300 \mathrm{~m}$ 水深 $0 \mathrm{~m} \sim 11 \mathrm{~m}$ の範囲の土砂量を求 めた. 図-5に鳥取砂丘海岸全体の土砂量の経年変化を示 す. 波浪同様に, 土砂量も季節変化を繰り返しながら, サンドリサイクル開始以降，その変動幅は大きくなりつ つも，全体の土砂量は増加傾向にあることがわかる。 ま た，大規模養浜期間には一時的に土砂量は増加し，その 後, 急減し, 大規模養浜以前の土砂量にもどりつつある ことがわかる. また, 鳥取港の浚渫土砂量を図-6に示す. 平成23年および 24 年の浚渫土砂量は他の年と比べて 1 2 万 $\mathrm{m}^{3}$ 程度多くなっている. 澁谷ら ${ }^{1}$ は投入された土砂の 一部は鳥取港にもどっていることを示しており，大規模 養浜の翌年に限って鳥取港の浚渫土砂量が増大している ことからも，土砂の一部は鳥取港内一流れたことが推測 される. しかし，土砂量の収支は合わないため，それ以 外は汀線部一寄与したか，もしくは流砂系外一流出した 可能性が考えられる. また，図-5から，平成24年3月か ら同年9月の期間は夏季の回復期にも関わらず土砂量は 減少している. この期間には有義波高が $4 \mathrm{~m}$ 程度, 有義波 周期が10sを超える高波浪が 2 度来襲しており, 静穏期に 高波浪が作用したことが原因と考えられる．それ以外に も静穏期に高波浪が作用した際（平成16年3月-9月，平成 20年3月-9月) には土砂量の減少や通常の増加よりも少な い増加が確認できる.

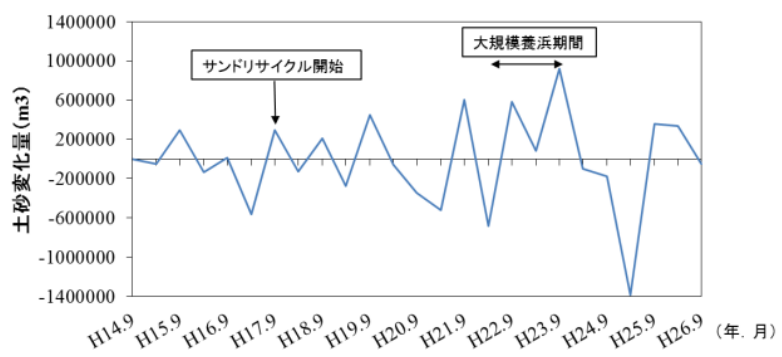

図-5＼cjkstart鳥取砂丘海岸の土砂量の経年変化

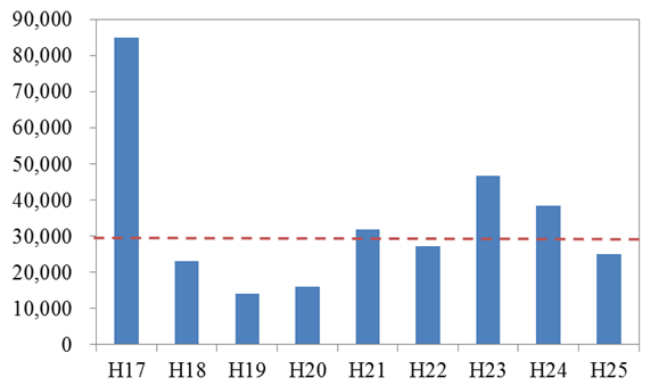

図-6 鳥取港の浚渫土砂量

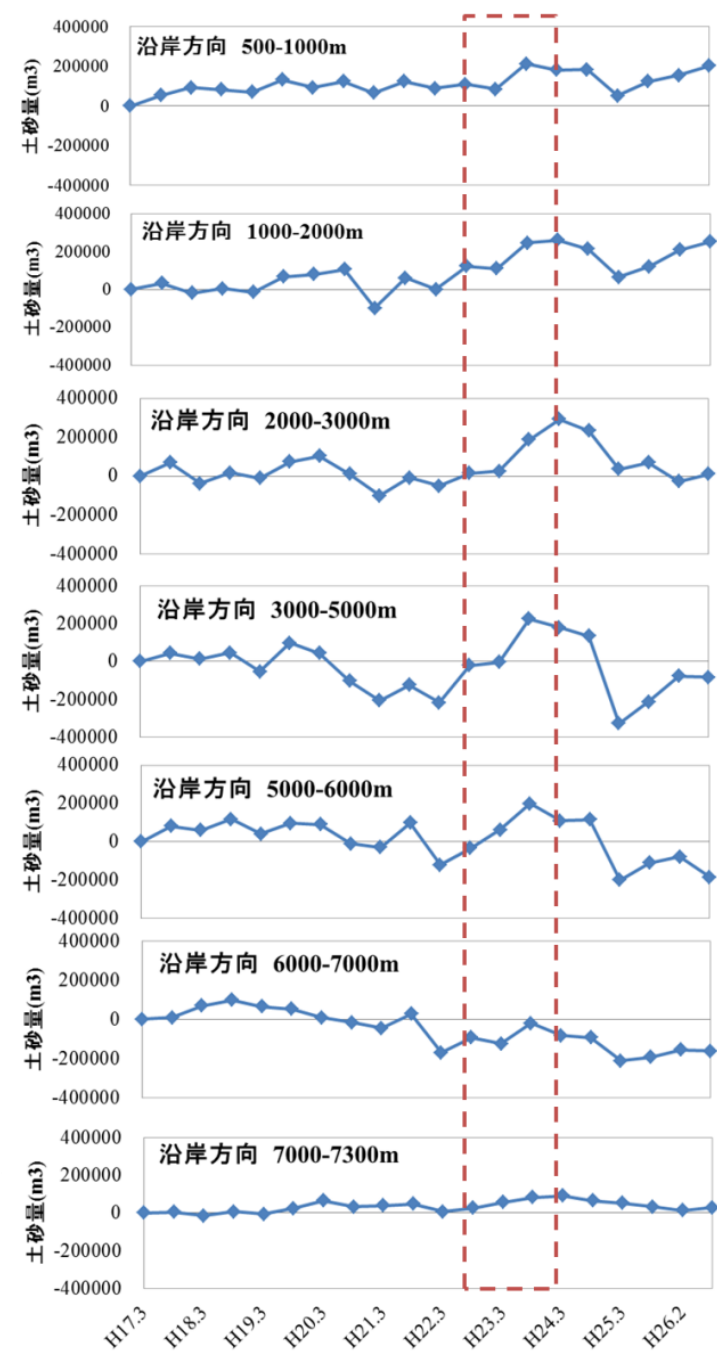

図-7 各区間における土砂量の経年変化

さらに，各区間における土砂量の経年変化を図-7に示

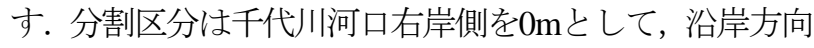
500-1000m, 1000-2000m, 2000-3000m, 3000-5000m, 5000-6000m，6000-7000m，7000-7300mである.ほぼす心 ての区間で，大規模養浜実施期間中（図中赤枠）に土砂 量が増加し，500-1000mおよび1000-2000m区間ではその 後も増加傾向である. 土砂投入区間の3000-5000mおよび その西側の2000-3000m区間の土砂量は大規模養浜以前 にもどっていることから，投入土砂は西側に移動したと 推測される. 沿岸方向6000-7000m, 7000-7300mの区間は 人工リーフによりほぼ安定している。また，5000-6000m 区間も人工リーフ区間であるが，整備中の人工リーフの 影響で土砂量が変動していると考えられる.

\section{4. 鳥取砂丘海岸の汀線変化}

\section{(1) 海岸全体の汀線変化}

平成 16 年 9 月から平成 26 年 2 月まで年 2 回実施され 
ている汀線測量結果（鳥取県土整備事務所提供）を用い て, サンドリサイクル開始以降の汀線変動の傾向を調べ る. 汀線測量は沿岸方向 $100 \mathrm{~m}$ 毎に実施されており，ま ず，側線ごとの汀線変化傾向に着目する. 図-8 は平成 16 年 9 月を基準に沿岸方向 $2000 \mathrm{~m}$ 地点の汀線の経年変 化を示したものであり，その傾向を表すため線形近似曲 線（回帰直線）の傾きを求めた. この傾きが正の場合堆 積傾向, 負の場合は侵食傾向ということになる. 沿岸方 向 $2000 \mathrm{~m}$ 地点の線形近似曲線の傾きは約 $0.77 \mathrm{~m} /$ 年であり， 期間全体として汀線は前進傾向であることがわかる。ま た，期間別にみると，大規模養浜期間に汀線は大きく前 進している. その後, 汀線は少し後退しているが, 現在 もある程度維持されていることがわかる. 同様に各側線 ごとに線形近似曲線の傾きを求め, 海岸全体の経年変化 の傾向を示したものが図-9 である. 図より，一部区間を 除いて，汀線は全体的に前進傾向である．侵食傾向の箇 所の汀線の経年変化を取り出し, 図-10 に示す. 沿岸方 向 $2600 \mathrm{~m}$ 地点および $4700 \mathrm{~m}$ 地点の汀線はサンドリサイ クル開始以降も侵食傾向であったが，大規模養浜期間お よびその後も前進傾向である. 特に, 大規模養浜による 土砂投入地点の沿岸方向 $4700 \mathrm{~m}$ では, 汀線は順調に前進 しており，養浜土砂が汀線部で維持され，また陸上貯留 の土砂の一部が汀線の前進に継続的に寄与しているので はないかと考えられる. 一方, 沿岸方向 $3400 \mathrm{~m}$ 地点, $5200 \mathrm{~m}$ 地点および7300m地点は大規模養浜期間に汀線は 一時的に前進しているものの, 全体としては侵食傾向で ある. 沿岸方向 $3400 \mathrm{~m}$ 地点は養浜土砂の影響により変動 量は大きく, 平成 26 年 2 月現在では回復しているが, 前 進傾向かどうかは不明である.この地点は鳥取砂丘前面 部であるため, 養浜位置の検討を踏まえ, 今後の変化に 注視する必要がある. 沿岸方向 $5000 \mathrm{~m}$ から 8000m 区間 は人工リーフ設置区間であり，5200m 地点は現在整備中 であるため, 人工リーフ完成後, 汀線の回復が期待され る. $7300 \mathrm{~m}$ 地点は隣接する人工リーフの設置角度が異な る地点であるため, 侵食傾向が見受けられる.以上より, 砂丘前面部の一部区間を除いて，大規模養浜実施にとも なって，汀線は概ね安定もしくは回復傾向にあることが わかった.

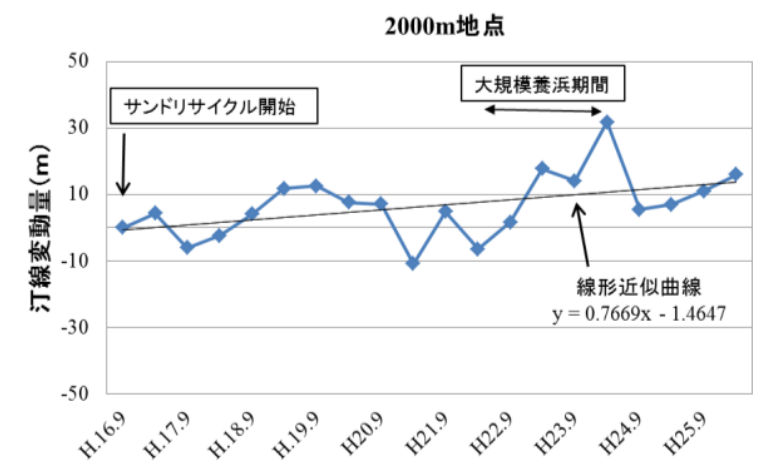

図-8 沿岸方向2000m地点の汀線の経年変化

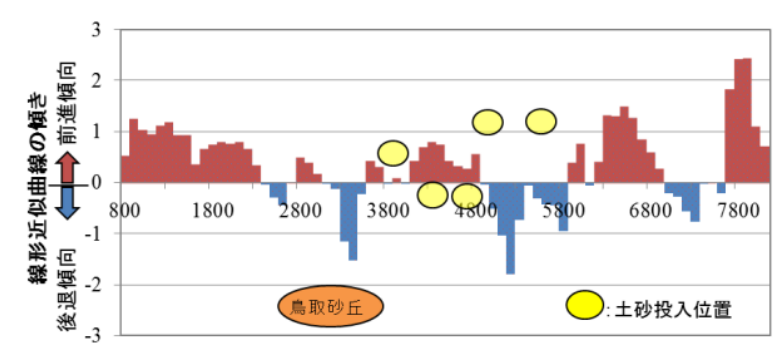

図-9 鳥取砂丘海岸全体の汀線の経年変化の傾向
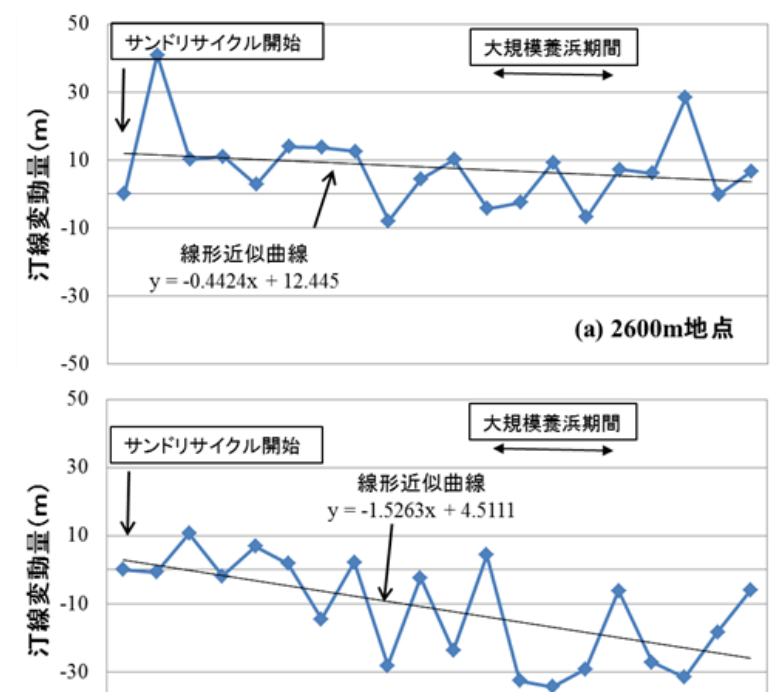

(b) $3400 \mathrm{~m}$ 地点

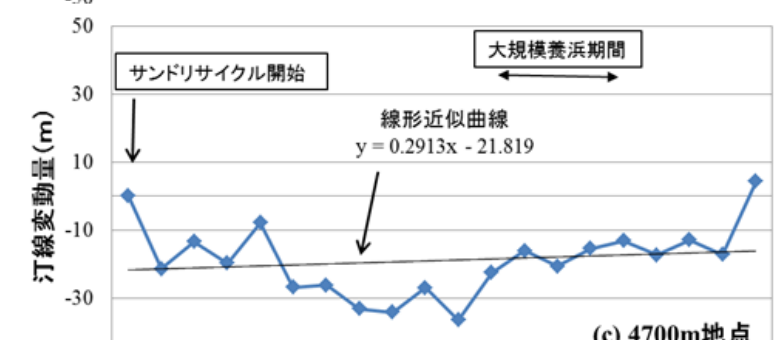

(c) $4700 \mathrm{~m}$ 地点
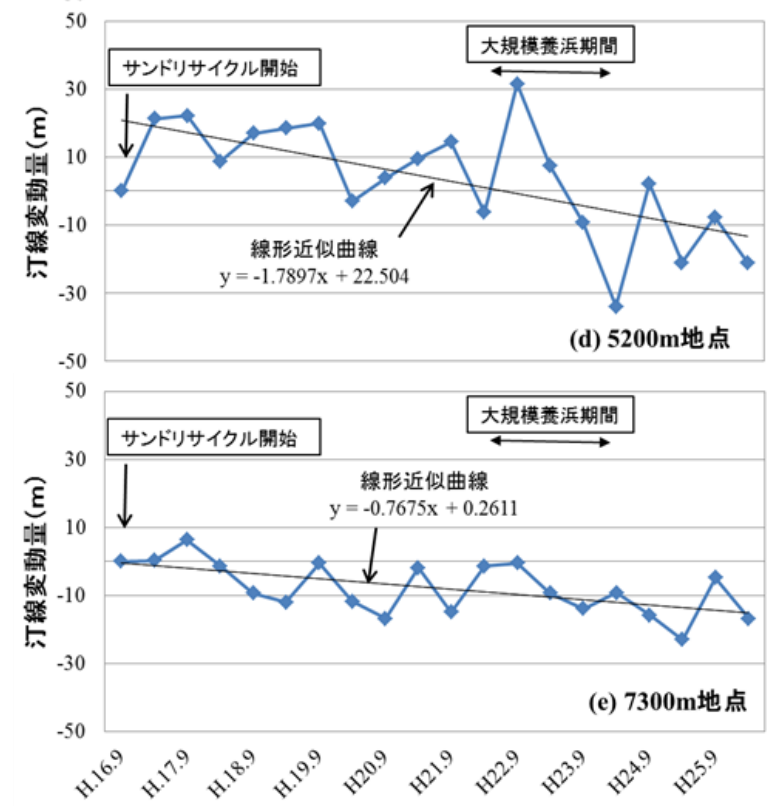

図-10 鳥取砂丘海岸全体の汀線の経年変化の傾向 


\section{(2) 土砂投入区間の汀線変化}

土砂投入区間において汀線変動をより詳細に把握す るために, 平成 21 年 11 月から平成 27 年 1 月まで月 2 回 程度 GPS を用いて汀線測量を行った. 図-11 は汀線測量 の結果の例を Google earth 上に重ね合わせたものである。 Royal Tek Data ロガーGPS 受信機(RGM-3800)を用い，取 得された位置情報をもとに, 沿岸方向 $20 \mathrm{~m}$ 毎に基線から の汀線位置を算出した. なお, 本研究で用いた GPS 受信 位の絶対制度は $10 \mathrm{~m}$ 程度とそれているが，相対誤差は $10 \mathrm{~cm}$ 程度であることを確認している. 測量範囲は陸上土 砂投入近辺の沿岸方向 $4000 \mathrm{~m}$ から $4700 \mathrm{~m}$ 付近である.

図-12 に平成 21 年 11 月から平成 27 年 1 月の汀線変化 を示す．土砂投入付近の汀線は概ね前進傾向であり，鳥 取県が実施している汀線測量結果とも一致する．さらに 詳細な汀線の経年変化を図-13 に示寸．図中の赤枠は大 規模養浜が行われた区間を表している．大規模養浜土砂 により汀線は前進し，その後も維持されていることがわ かる. 養浜位置より西側にあたる沿岸方向 4300m および $4400 \mathrm{~m}$ では多少汀線は後退しているが，平成 27 年 1 月 時点においても大規模養浜以前より $20 \sim 40 \mathrm{~m}$ 程度汀線 が前進している．土砂投入区間である沿岸方向 $4500 \mathrm{~m}$, 4600m 地点の汀線は維持されているが，現在も背後に陸 上貯留された土砂が残っている地点である. 汀線変化と 陸上貯留土砂の関係を調べるため，断面測量を行い，陸 上貯留土砂量を算出した (表-2). 表より, 陸上貯留土 砂は著しく減少していないことがわかる，よって，土砂 投入付近の汀線は多量の土砂により前進した後, 留まり 侵食することなく維持されていることがわかった.

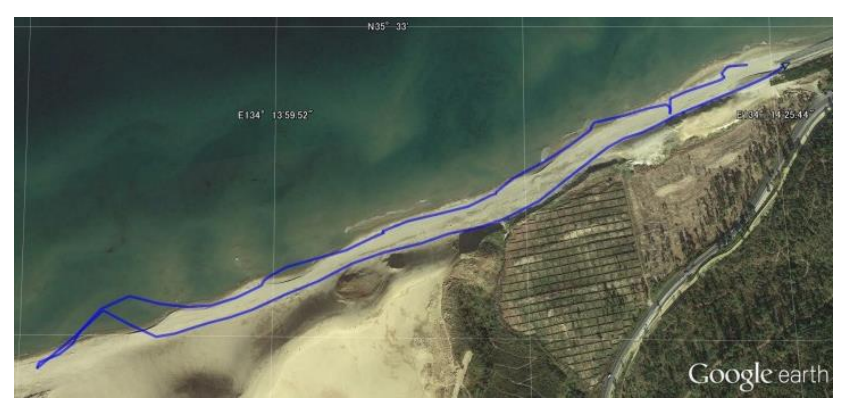

図-11 汀線測量結果の例

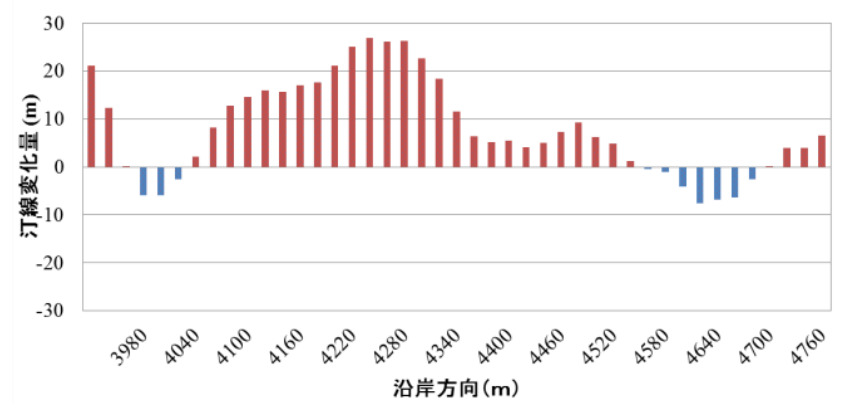

図-12 汀線変化量（平成27年1月-平成21年11月）

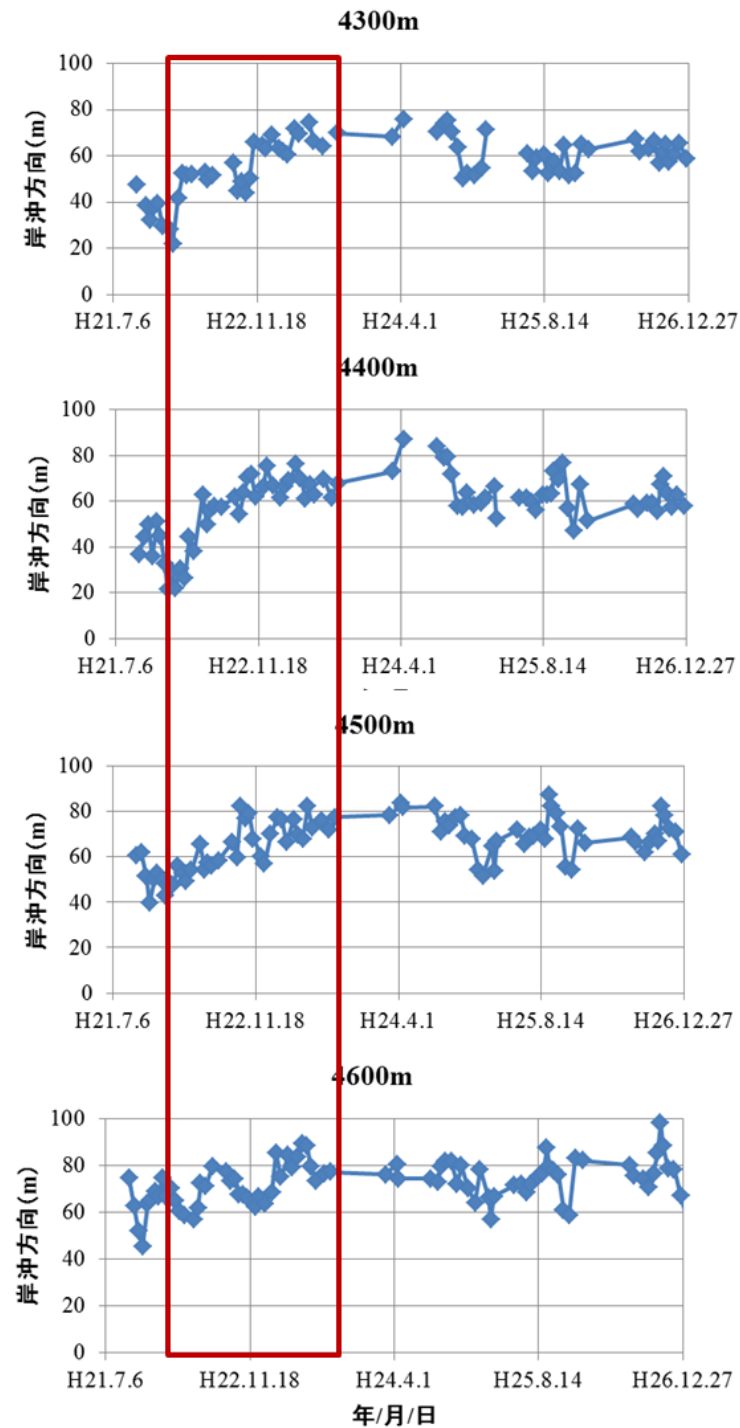

図-13 汀線測量結果の例

表-2 陸上貯留土砂量と変化量

\begin{tabular}{|c|r|r|}
\hline & \multicolumn{1}{|c|}{ 体積 $\left(\mathrm{m}^{3}\right)$} & 土砂変化量 $\left(\mathrm{m}^{3}\right)$ \\
\hline 平成25年10月18日 & 17,607 & \\
\hline 平成25年12月19日 & 16,557 & $-1,051$ \\
\hline 平成26年1月16日 & 16,245 & -312 \\
\hline
\end{tabular}

\section{5. おわりに}

本研究では，鳥取県で行われているサンドリサイクル の取り組みの効果を引き続き検証するとともに，平成22 年度, 23年度に行われた大規模養浜の効果とその後の安 定性の検討を行った。

鳥取砂丘海岸全体の土砂量は季節的な増減を繰り返 しており，大規模養浜により一時的に増加したが，その 後, 大規模養浜以前の土砂量に戻りつつある．鳥取港の 浚渫土砂は大規模養浜が行われた翌年の平成23年度およ び24年度は若干増加したが，大規模養浜土砂量に匹敵す 
る量ではなかった。このことから，養浜土砂は汀線の前 進に寄与し，現在もある程度維持されていると考えられ る. また, 汀線変化の傾向は全体としては概ね前進傾向 であり，サンドリサイクル開始以降も侵食傾向であった 箇所も，大規模養浜後，汀線は前進している．特に，陸 上土砂投入地点付近でその傾向が顕著であり，また大規 模養浜終了後も汀線は維持されている. 現在も陸上に貯 留された土砂が残っているが，著しく減少しておらず, 高波浪作用時など一時的もしくは突発的な侵食の食い止 めが期待される. しかし, 汀線が今後維持され続けるか 否かは不明であり, どの程度持続するのか引き続きモ二 タリングが必要である. また汀線維持の要因の究明のた めにも，粒径分布調査を行うことが望まれる，鳥取県で は全国的にも早い段階から土砂投入による侵食対策が行 われてきており, 本研究が, 今後のより効果的な海岸侵 食対策の一助となれば幸いである.

謝辞：本研究を遂行するにあたり，鳥取県県土整備部鳥 取県土整備事務所にデータを提供いただき，鳥取県県土 整備部河川課の土砂管理連絡調整会議資料を参考にさせ
ていただいた。 また，本研究は，日本学術振興会 基盤 研究 (C) の研究成果の一部である.ここに記して謝意 を表す。

\section{参考文献}

1) 涉谷容子・松原雄平・黒岩正光・井出正志 : 鳥取砂丘 海岸における土砂動態把握およびサンドリサイクル の効果の検討, 土木学会論文集 B2(海岸工学), Vol.68, pp. II 676-680, 2012.

2) 宇多高明・岡村真・西村洋人 : 鳥取海岸の沖合部にお ける地形変化, 第 33 回海岸工学論文集, pp. 282-286, 1986.

3) 鳥取県：鳥取沿岸の総合的な土砂管理ガイドライン, 2005.

4) 鳥取県: 平成 26 年度鳥取県東部沿岸土砂管理連絡調 整会議資料, 2014 .

5) Y.Shibutani, Y. Matsubara and M. Kuroiwa : Effect of the coastal conservation due to beach nourishment of Tottori Sand Dune Coast, Proceedings of the 7th International Conference on Asian and Pacific Coasts, pp.78-84, 2013.

6) 安本善征・宇多高明・松原雄平 : 鳥取沿岸の侵食実態 と総合的な土砂管理の検討一千代川右岸流砂系の例 一, 海岸工学論文集, 第 53 巻, pp. 641-645, 2006.

\title{
EXAMINATION OF THE COASTAL CONSERVATION DUE TO LARGE-SCALE BEACH NOURISHMENT AT TOTTORI SAND DUNE COAST
}

\author{
Yoko SHIBUTANI, Naoki TAMURA, Keigo OTA \\ Masamitsu KUROIWA and Yuhei MATSUBARA
}

Tottori Sand Dune Coast has been eroded starting around 1940s and the beach nourishment project has been carried out to restore the shoreline since 2005. In the project, the deposition sand at port and river mouth were dredged and transported to the erosional area. And then the sand was injected in the region offshore erosional area and the backshore area. The total volume of the sand was approximately $650,000 \mathrm{~m}^{3}$ from 2005 to 2014 . In this study, the effect of the project was estimated using the bottom sounding data and the shoreline data. The shorelines showed trend to restore after the beach nourishment project. From this study, it was found that although a part of injected sediments was moved to the Tottori port, recovery of the shoreline was maintained. 